\title{
Reformasi Administrasi Perpajakan, Implementasi Penerapan E-Faktur dan Kepatuhan Pelaporan Wajib Pajak
}

\author{
Putu Desy Ari Paramitha ${ }^{1}$ \\ Fakultas Ekonomi dan Bisnis \\ Universitas Udayana, Indonesia
}

\author{
Ni Luh Supadmi \\ Fakultas Ekonomi dan Bisnis \\ Universitas Udayana, Indonesia
}

Surel : desyariparamitha@yahoo.com

\section{ABSTRAK}

Penelitian ini bertujuan untuk mengetahui pengaruh dari reformasi administrasi perpajakan dan penerapan $e$-faktur pada kepatuhan pelaporan Pengusaha Kena Pajak (PKP). Metode untuk menentukan sampel menggunakan Accidental Sampling. Jumlah sampel sebanyak 73 responden yang didapat dari perhitungan sampel dengan rumus slovin. Data dikumpulkan dengan kuisioner menggunakan skala likert 4 poin. Analisis data menggunakan teknik analisis regresi linier berganda. Dari hasil analisis data, hasil penelitian adalah adanya pengaruh positif dan signifikan dari penerapan reformasi administrasi perpajakan dan penerapan E-faktur pada kepatuhan PKP dalam melakukan pelaporan pajak.

Kata Kunci: Reformasi Administrasi Perpajakan; Implementasi E-Faktur; Kepatuhan Pelaporan PKP.

\section{Tax Administration Reform, Implementation of E-Invoice Application and Taxpayer Reporting Compliance}

\section{ABSTRACT}

This study aims to determine how the influence of tax administration reforms that are applied as well as the application of e-invoices on tax compliance reporting of taxable entrepreneurs (PKP). The method for determining the sample is using the Accidental Sampling method. The number of samples is 73 respondents obtained from sample calculations with Slovin formula. Data collected by questionnaire. The questionnaire uses a 4-point Likert scale. Data analysis uses multiple linear regression analysis techniques. From the results of data analysis, the results obtained are a positive and significant relationship from the implementation of tax administration reforms and the application of einvoices to PKP compliance in tax reporting.

Keywords: Tax Administration Reform; E-Invoice Implementation; PKP Reporting Compliance.

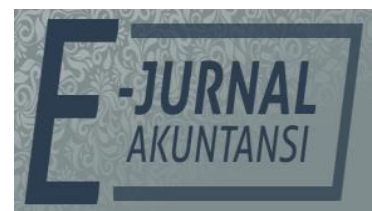

e-ISSN 2302-8556

Vol. 31 No. 3

Denpasar, Maret 2021 Hal. 540-550

DOI:

10.24843/EJA.2021.v31.i03.p02

PENGUTIPAN:

Paramitha, P.D.A., \&

Supadmi, N.L. (2021).

Reformasi Administrasi

Perpajakan, Implementasi

Penerapan E-Faktur dan Kepatuhan Pelaporan Wajib Pajak. E-Jurnal Akuntansi, 31(3), 540-550

RIWAYAT ARTIKEL:

Artikel Masuk: 26 Desember 2019 Artikel Diterima: 8 Februari 2021

Artikel dapat diakses : https://ojs.unud.ac.id/index.php/Akuntansi/index 


\section{PENDAHULUAN}

Sejak tahun 2002, Direktorat Jendral Pajak (DJP) telah melakukan reformasi system administrasi perpajakan dengan membentuk Kantor Pelayanan Pajak modern, amandemen UU KUP (Undang-Undang Ketentuan Umum dan Tata Cara Perpajakan) dan PPh (Pajak Penghasilan) serta menerbitkan program Sunset Policy. Upaya - upaya perubahan ini dilakukan DJP pada reformasi perpajakan jilid I. Reformasi ini berlangsung hingga tahun 2008. Setelah dilakukannya reformasi jilid I, pada tahun 2009 DJP kembali memulai reformasi perpajakan jilid II yang berlangsung hingga tahun 2014. Pada reformasi jilid kedua, DJP melakukan beberapa terobosan yaitu amendemen Undang-Undang Pajak Pertambahan Nilai dan Pajak Penjualan Barang Mewah serta Sensus Pajak Nasional (Arif, 2019). Saat ini reformasi perpajakan jilid ketiga sedang berlangsung dan ditargetkan akan rampung pada tahun 2020.

E-Faktur ini diberlakukan dengan tujuan terhubung langsung dengan pembuatan E-SPT Masa PPN sehingga pemungutan PPN dan transaksi mudah dicek, menghindari Faktur Pajak yang tidak valid, keamanan dari segi data terjamin, menghemat biaya dan waktu, serta mudah dan efisien. Hal tersebut tentu saja memberikan kemudahan, kenyamanan, dan keamanan bagi Pengusaha Kena Pajak dalam melaksanakan kewajiban perpajakannya, terutama dalam pembuatan faktur pajak dan E-SPT Masa PPN. Pemantauan yang dilakukan terkait dengan faktur pajak elektronik dapat dilakukan dengan lebih optimal karena pelaporan dilakukan dengan cara mengunggah (upload) sehingga pelaporannya lebih bersifat real-time, kerahasiaan data dan keamanan data pun lebih terjamin. DJP menyediakan serta menentukan aplikasi khusus untuk membuat faktur pajak. Aplikasi tersebut dapat diakses dengan mudah.

Hasil penelitian sebelumnya, yaitu Lingga (2015) menemukan adanya pengaruh dari penerapan E-SPT pada efisiensi pengisian SPT. Penelitian Wijayanti \& Merkusiwati (2017) serta Novaria (2019) juga menyatakan hasil yang serupa bahwa adanya pengaruh positif antara E-system perpajakan pada kepatuhan wajib pajak. Namun, hasil berbeda diperoleh dalam penelitian Lintang et al. (2016) yang menyatakan bahwa penerapan E-Faktur masih tergolong kurang efektif dalam hal meningkatkan kepatuhan pengusaha kena pajak. Sedangkan menurut penelitian Rahayu (2017), E-Faktur berpengaruh negatif dan signifikan terhadap kepatuhan wajib pajak.

Gambaran tingkat kepatuhan dari jumlah Surat Pemberitahuan (SPT) Tahunan Wajib Pajak PKP yang menggunakan E-Faktur, yang masuk di KPP Pratama Denpasar Timur disajikan pada Tabel 1, menunjukkan bahwa wajib pajak PKP yang menggunakan E-Faktur jumlahnya yang lebih kecil dibandingkan dengan wajib pajak PKP yang terdaftar di KPP Denpasar Timur. Wajib pajak PKP yang menyampaikan SPT juga terus mengalami penurunan dari tahun 2013 hingga 2017.

Penelitian ini menggunakan Theory of Planned Behavior (TPB) (Ajzen, 1991), untuk menjelaskan mengenai faktor yang mempengaruhi seseorang melakukan suatu tindakan, yaitu tindakan dari PKP dalam memanfaatkan $E$-faktur dan $E$ SPT dalam pelaporan pajak dengan memanfaatkan teknologi informasi. Pemanfaatan teknologi informasi dijelaskan dengan Technology Acceptance Model (TAM). 
Tabel 1. Tingkat Kepatuhan Wajib Pajak PKP di Kantor Pelayanan Pajak Pratama Denpasar Timur Tahun 2013-2017

\begin{tabular}{lllllll}
\hline No & Tahun & $\begin{array}{c}\text { Wajib Pajak } \\
\text { PKP yang } \\
\text { Terdaftar }\end{array}$ & $\begin{array}{c}\text { Wajib Pajak PKP } \\
\text { yang } \\
\text { menggunakan e- } \\
\text { Faktur }\end{array}$ & $\begin{array}{c}\text { Wajib Pajak PKP } \\
\text { yang } \\
\text { Menyampaikan } \\
\text { SPT }\end{array}$ & $\begin{array}{c}\text { \% Tingkat } \\
\text { Kepatuhan } \\
\text { (b/a*100) }\end{array}$ \\
\hline 1 & 2013 & 332 & 216 & 98 & 45,37 \\
2 & 2014 & 316 & 206 & 63 & 30,58 \\
3 & 2015 & 298 & 212 & 79 & 37,26 \\
4 & 2016 & 283 & 198 & 57 & 28,79 \\
5 & 2017 & 267 & 186 & 49 & 26,34 \\
\hline
\end{tabular}

Sumber: KPP Pratama Denpasar Timur, 2019

Menurut Mardiasmo (2016), terdapat beberapa faktor yang dapat mempengaruhi kepatuhan dari WP. Pertama yaitu kondisi sistem administrasi perpajakan. WP tentunya menginginkan sistem administrasi yang efisien dan efektif. Kedua adalah pelayanan pada Wajib Pajak. Pelayanan disini berhubungan dengan SDM. Pemberian informasi yang informatif dan sesuai kebutuhan WP merupakan salah satu pelayanan yang dapat diberikan kepada WP. Faktor ketiga yaitu penegakan hukum perpajakan dan faktor terakhir yaitu pemeriksaan pajak dan tarif pajak. Fasmi \& Misra (2014) serta Antari \& Supadmi (2019) dalam penelitian yang dilakukannya mengenai modernisasi sistem administrasi perpajakan mendapatkan hasil bahwa modernisasi sistem administrasi perpajakan memiliki pengaruh signifikan pada tingkat kepatuhan pengusaha kena pajak. Apriliana (2013) serta Punarbhawa \& Aryani (2013) juga menemukan adanya pengaruh positif antara reformasi administrasi perpajakan dengan kepatuhan wajib pajak. Namun, hasil berbeda diperoleh dalam penelitian Hartiyah \& Suryanita (2015) yang menyatakan bahwa tidak terdapat pengaruh positif antara modernisasi sistem administrasi perpajakan dengan tingkat kepatuhan Pengusaha Kena Pajak. Berlandaskan pada hasil penelitian terdahulu, maka dikembangkan hipotesis sebagai berikut.

$\mathrm{H}_{1}$ : Reformasi administrasi perpajakan berpengaruh positif dan signifikan terhadap kepatuhan pelaporan PKP di KPP Pratama Denpasar Timur.

Menurut Rahayu (2017) "administrasi perpajakan (Tax Administration) ialah cara-cara atau prosedur pengenaan dan pemungutan pajak. Administrasi perpajakan berperan penting dalam sistem perpajakan di suatu Negara, suatu Negara dapat dengan sukses mencapai sasaran yang diharapkan dalam menghasilkan penerimaan pajak yang optimal karena administrasi perpajakannya mampu dengan efektif melaksanakan sistem perpajakan di suatu Negara yang dipilih". Agustin (2016) melakukan penelitian mengenai topik pengaruh aplikasi E-Faktur pada kepatuhan WP badan dan menemukan adanya pengaruh positif antara kedua variabel tersebut. Sebelum adanya E-Faktur WP dihadapkan dengan kemungkinan terkena sanksi yang lebih besar dikarenakan kesalahan-kesalahan akibat kurangnya pemahaman dari WP. Dengan adanya $E-$ Faktur yang merupakan fasilitas yang disediakan oleh DJP, ada rasa percaya dan aman oleh WP sehingga WP lebih dimudahkan. Untuk menjelaskan bagaimana PKP memanfaatkan E-faktur serta E-SPT dalam melakukan pelaporan didasari 
dari Technology Acceptance Model (TAM). TAM memberikan pemahaman mengenai pemanfaatan teknologi oleh pengguna. Rizqiah et al. (2014) dan Lingga (2015) dalam penelitiannya yang mengangkat topik serupa yaitu mengenai implementasi E-Faktur pada kepatuhan pelaporan wajib pajak badan menemukan hasil yang sama yaitu kedua variabel tersebut berpengaruh positif. Penelitian Wijayanti \& Merkusiwati (2017) serta Novaria (2019) juga menyatakan hasil yang serupa bahwa adanya pengaruh positif antara $E$-system perpajakan pada kepatuhan wajib pajak. Hipotesis yang dapat dirumuskan dari hal tersebut yaitu:

$\mathrm{H}_{2}$ : Implementasi E-Faktur berpengaruh positif dan signifikan terhadap kepatuhan pelaporan PKP di KPP Pratama Denpasar Timur.

\section{METODE PENELITIAN}

Lokasi penelitian ini adalah Kantor Pelayanan Pajak Pratama Denpasar Timur. Objek penelitian adalah kepatuhan pelaporan PKP di KPP Pratama Denpasar Timur, khususnya berkaitan dengan reformasi Administrasi Perpajakan dan Implementasi Penerapan E-Faktur. Variabel independen pertama $\left(\mathrm{X}_{1}\right)$ adalah reformasi administrasi. Indikator yang digunakan untuk mengukur reformasi administrasi adalah Modernisasi Struktur Organisasi, Modernisasi Prosedur Organisasi, Modernisasi Strategi Organisasi, Modernisasi Budaya Organisasi (Fadhilah, 2014).

Variabel independen kedua $\left(\mathrm{X}_{2}\right)$ dalam penelitian ini adalah implementasi E-Faktur. Indikator yang digunakan untuk mengukur implementasi E-Faktur adalah Urgensi Diterapkannya sistem E-Faktur, Tujuan Penerapan E-Faktur, Sosialisasi kepada Pengusaha Kena Pajak (PKP), Penerapan E-Faktur (Nopiana \& Natalia, 2018). Menurut Rachmatulloh \& Pamungkas (2017) untuk mengukur implementasi E-Faktur dapat ditinjau dari tiga dimensi sebagai berikut: Menghitung pajak dengan benar, Ketepatan Waktu pajak, Melaksanakan peraturan perpajakan yang berlaku.Populasi dalam penelitian ini adalah seluruh PKP yang terdaftar di Kantor Pelayanan Pajak Pratama Denpasar Timur, yakni sebanyak 267 Pengusaha Kena Pajak. Penentuan jumlah sampel menggunakan rumus Slovin dan diperoleh hasil sebanyak 73 responden. Pemilihan sampel dilakukan dengan teknik Accidental Sampling. Metode yang digunakan untuk mengumpulkan data penelitian adalah kuisioner yang dibagikan kepada 73 PKP yang terdaftar di KPP Denpasar Timur.

\section{HASIL DAN PEMBAHASAN}

Berdasarkan data yang dikumpulkan melalui penyebaran kuisioner kepada 73 responden, berikut akan disajikan karakteristik responden berdasarkan jenis kelamin disajikan pada Tabel 2.

Tabel 2. Distribusi Responden Berdasarkan Jenis Kelamin

\begin{tabular}{lll}
\hline Jenis Kelamin & Jumlah Responden & Persentase ( persen) \\
\hline Pria & 45 & 61,64 \\
Wanita & 28 & 38,35 \\
Jumlah & 73 & 100 \\
\hline
\end{tabular}

Sumber : Data Penelitian, 2020 
Berdasarkan Tabel 2, dari 73 responden, didapatkan hasil bahwa 45 dari 73 responden adalah pria yaitu sebesar 61,64 persen yang berarti mayoritas PKP adalah pria dan sisanya yaitu 28 responden atau sebesar 38,35 persen adalah wanita.

Berdasarkan data yang dikumpulkan melalui penyebaran kuisioner kepada 73 responden, berikut akan disajikan karakteristik responden berdasarkan tingkatan usia disajikan pada Tabel 3.

Tabel 3. Distribusi Responden Berdasarkan Tingkatan Usia

\begin{tabular}{lll}
\hline Tingkat umur (tahun) & Jumlah (orang) & Persentase ( persen) \\
\hline $20-30$ & 30 & 41,09 \\
$31-40$ & 34 & 46,57 \\
$>40$ & 9 & 12,33 \\
Jumlah & 73 & 100 \\
\hline
\end{tabular}

Sumber: Data Penelitian, 2019

Berdasarkan Tabel 3, dari 73 responden, mayoritas PKP yang terdaftar berkisar di usia 31 hingga 40 tahun atau 46,57 persen. Hal ini dapat dilihat dari Tabel 3, dimana 34 responden dari total 73 responden berkisar pada usia tersebut. Sebanyak 30 responden atau 41,09 persen adalah responden pada tingkatan umur 20 hingga 30 tahun. Sisanya sebanyak 9 responden atau 12,33 persen adalah responden pada tingkatan usia diatas 40 tahun.

Berdasarkan data yang dikumpulkan melalui penyebaran kuisioner kepada 73 responden, berikut akan disajikan karakteristik responden berdasarkan pendidikan disajikan pada Tabel 4 .

Tabel 4. Distribusi Responden Berdasarkan Pendidikan

\begin{tabular}{lll}
\hline Pekerjaan & Jumlah (Orang) & Persentase (persen) \\
\hline Diploma & 13 & 17,81 \\
S1 & 30 & 41,09 \\
S2 & 24 & 32,88 \\
S3 & 6 & 8,22 \\
Total & 73 & 100 \\
\hline Sumber: Data Penelition, 2019 &
\end{tabular}

Sumber: Data Penelitian, 2019

Berdasarkan Table 4, dari 73 responden, PKP yang memiliki latar belakang pendidikan S1 sebanyak 30 orang. Latar belakang pendidikan S1 dinilai telah memilliki pemahaman yang lebih matang mengenai perpajakan baik dalam perhitungan maupun pelaporan. Terbanyak kedua adalah S2 yaitu sebanyak 24 responden, ketiga adalah diploma yaitu sebanyak 13 responden dan terakhir adalah S3 sebanyak 6 responden. Pengujian instrumen penelitian diperlukan untuk memastikan validnya suatu instrument yang digunakan dalam penelitian. Hasil dari uji validitas disajikan pada Tabel 5, berikut.

Berdasarkan Tabel 5, hasil uji validitas penelitian menunjukan bahwa instrumen penelitian ini valid yang berarti layak untuk digunakan mengukur variabel-variabel yang digunakan dalam penelitian. Kesimpulan ini didapat dari nilai koefisien korelasi dengan skor total seluruh item pernyataan melebihi 0,30 dengan signifikansi kurang dari 0,05. 
Tabel 5. Rekapitulasi Hasil Uji Validitas Instrumen Penelitian

\begin{tabular}{lllll}
\hline Variabel & Indikator & $\begin{array}{l}\text { Koefisien } \\
\text { Korelasi }\end{array}$ & $\begin{array}{l}\text { Sig. } \\
(2-\text { tailed })\end{array}$ & Keterangan \\
\hline & $\mathrm{X}_{1.1}$ & 0,547 & 0,000 & Valid \\
& $\mathrm{X}_{1.2}$ & 0,632 & 0,000 & Valid \\
Reformasi & $\mathrm{X}_{1.3}$ & 0,632 & 0,000 & Valid \\
administrasi pajak & $\mathrm{X}_{1.4}$ & 0,628 & 0,000 & Valid \\
$\left(\mathrm{X}_{1}\right)$ & $\mathrm{X}_{1.5}$ & 0,662 & 0,000 & Valid \\
& $\mathrm{X}_{1.6}$ & 0,629 & 0,000 & Valid \\
& $\mathrm{X}_{1.7}$ & 0,452 & 0,000 & Valid \\
& $\mathrm{X}_{1.8}$ & 0,526 & 0,000 & Valid \\
& $\mathrm{X}_{2.1}$ & 0,419 & 0,000 & Valid \\
& $\mathrm{X}_{2.2}$ & 0,560 & 0,000 & Valid \\
Implementasi E-Faktur & $\mathrm{X}_{2.3}$ & 0,490 & 0,000 & Valid \\
$\left(\mathrm{X}_{2.4}\right)$ & $\mathrm{X}_{2.5}$ & 0,623 & 0,000 & Valid \\
& $\mathrm{X}_{2.6}$ & 0,569 & 0,000 & Valid \\
& $\mathrm{X}_{2.7}$ & 0,513 & 0,000 & Valid \\
& $\mathrm{X}_{2.8}$ & 0,463 & 0,000 & Valid \\
& $\mathrm{Y}_{1}$ & 0,405 & 0,000 & Valid \\
& $\mathrm{Y}_{2}$ & 0,568 & 0,000 & Valid \\
& $\mathrm{Y}_{3}$ & 0,635 & 0,000 & Valid \\
Kepatuhan pelaporan & $\mathrm{Y}_{4}$ & 0,560 & 0,000 & Valid \\
PKP (Y) & $\mathrm{Y}_{5}$ & 0,670 & 0,000 & Valid \\
& $\mathrm{Y}_{6}$ & 0,353 & 0,000 & Valid \\
& $\mathrm{Y} 7$ & 0,675 & 0,002 & Valid \\
& $\mathrm{Y}_{8}$ & 0,441 & 0,000 & Valid \\
& & & 0,000 & Valid \\
\hline
\end{tabular}

Sumber: Data Penelitian, 2019

Keandalan variabel dalam suatu penelitian perlu dinilai dan penilaian ini dilakukan dengan melakukan uji reliabilitas instrumen. Hasil dari uji reliabilitas disajikan pada Tabel 6 .

Tabel 6. Rekapitulasi Hasil Uji Reliabilitas Instrumen Penelitian

\begin{tabular}{llll}
\hline No. & Variabel & Cronbach's Alpha & Keterangan \\
\hline 1 & Reformasi administrasi pajak $\left(\mathrm{X}_{1}\right)$ & 0,743 & Reliabel \\
2 & Implementasi E-Faktur $\left(\mathrm{X}_{2}\right)$ & 0,715 & Reliabel \\
3 & Kepatuhan pelaporan PKP $(\mathrm{Y})$ & 0,719 & Reliabel \\
\hline
\end{tabular}

Sumber: Data Penelitian, 2019

Pada Tabel 6, Menunjukan bahwa ketiga variabel tersebut reliabel dan dapat digunakan dalam penelitian dengan nilai koefisien Cronbach's Alpha yang melebihi 0,60. Hasil dari uji statistik deskriptif disajikan pada Tabel 7.

Tabel 7. Hasil Statistik Deskriptif Variabel Penelitian

\begin{tabular}{llllll}
\hline & $\mathrm{N}$ & Minimum & Maximum & Mean & Std. Deviation \\
\hline Reformasi Administrasi Pajak & 3 & 17.00 & 32.00 & 24.4521 & 3.47228 \\
Implementasi E-Faktur & 3 & 17.00 & 31.00 & 24.8356 & 2.86266 \\
Kepatuhan Pelaporan Wajib & 3 & 17.00 & 30.00 & 25.2603 & 2.94876 \\
Pajak & & & & & \\
Valid N (listwise) & 3 & & & & \\
\hline
\end{tabular}

Sumber: Data Penelitian, 2019 
Berdasarkan Tabel 7, uji statistik deskriptif dimana pengujian ini memaparkan nilai minimum, maksimum, mean serta std deviation dari tiap variabel yang digunakan dalam penelitian.

Untuk mengetahui distribusi dari persamaan regresi yang digunakan perlu dilakukan pengujian yaitu uji normalitas. Hasil uji normalitas disajikan pada Tabel 8.

\section{Tabel 8. Hasil Uji Normalitas}

\begin{tabular}{ll}
\hline & Unstandardized Residual \\
\hline $\mathrm{N}$ & 73 \\
Kolmogorov-Smirnov Z & 0,493 \\
Asymp.Sig.(2-tailed) & 0,968 \\
\hline
\end{tabular}

Sumber: Data Penelitian, 2019

Berdasarkan Tabel 8, hasil dari uji normalitas menunjukkan KolmogorovSmirnov yang melebihi 0,05 yaitu 0,493 dengan signifikansi sebesar 0,968 maka model persamaan regresi berdistribusi normal. Hasil uji multikolinearitas disajikan pada Tabel 9, berikut.

Tabel 9. Hasil Uji Multikoleniaritas

\begin{tabular}{llll}
\hline Variabel & Tolerance & VIF & Keterangan \\
\hline Reformasi administrasi pajak $\left(\mathrm{X}_{1}\right)$ & 0,487 & 2,052 & Bebas multikol \\
Implementasi E-Faktur $\left(\mathrm{X}_{2}\right)$ & 0,487 & 2,052 & Bebas multikol \\
\hline
\end{tabular}

Sumber: Data Penelitian, 2019

Berdasarkan Tabel 9, disajikan hasil dari uji multikolinearitas untuk variable bebas yang digunakan dalam variabel bebas dalam penelitian ini. Untuk terbebas dari multikolinearitas variabel bebas perlu mendapatkan nilai tolerance yang melebihi 10 persen serta nilai VIF yang kurang dari 10. Berdasarkan Tabel 9, kedua variabel bebas yang digunakan dalam penelitian tidak terdapat multikolinearitas.

Uji heteroskedastisitas dilakukan untuk mengetahui apakah variable bebas yang digunakan terdapat heteroskedastisitas atau tidak.Berikut pada Tabel 10, disajikan hasil uji heteroskedastisitas.

Tabel 10. Hasil Uji Heteroskedastisitas

\begin{tabular}{llll}
\hline No & Variabel Bebas & Signifikansi & Keterangan \\
\hline 1 & Reformasi administrasi pajak & 0,577 & Bebas heteros \\
2 & Implementasi E-Faktur & 0,081 & Bebas heteros \\
\hline
\end{tabular}

Sumber: Data Penelitian, 2019

Hasil dari uji heteroskedastisitas dimana variabel bebas dalam penelitian dapat terbebas dari heteroskedastisitas jika mendapatkan nilai signifikansi yang melebihi 0,05. Berdasarkan Tabel 10, didapatkan hasil bahwa kedua variabel bebas yang digunakan dalam penelitian telah terbebas dari heteroskedastisitas. Hasil dari analisis regresi linier berganda disajikan pada Tabel 11, berikut.

Persamaan regresi berdasarkan Tabel 11, yaitu.

$$
Y=4,538+0,280 X_{1}+0,559 X_{2}
$$

Pada Tabel 11, didapatkan hasil bahwa variabel bebas dalam penelitian berpengaruh positif pada variabel terikat. Hal ini dapat dilihat dari nilai koefisien regresi yang bernilai positif. 
Tabel 11. Hasil Analisis Regresi Linier Berganda

\begin{tabular}{|c|c|c|c|c|c|c|}
\hline \multirow{2}{*}{\multicolumn{2}{|c|}{ Model }} & \multicolumn{2}{|c|}{$\begin{array}{l}\text { Unstandardized } \\
\text { Coefficients }\end{array}$} & \multicolumn{2}{|l|}{$\begin{array}{l}\text { Standardized } \\
\text { Coefficients }\end{array}$} & \multirow[b]{2}{*}{ Sig. } \\
\hline & & $\mathrm{B}$ & Std. Error & Beta & $t$ & \\
\hline \multirow[t]{3}{*}{1} & (Constant) & 4,538 & 1,814 & & 2,502 & 0,015 \\
\hline & Reformasi & 0,280 & 0,085 & 0,330 & 3,300 & 0,002 \\
\hline & $\begin{array}{l}\text { Administrasi Pajal } \\
\text { Implementasi E- } \\
\text { Faktur }\end{array}$ & 0,559 & 0,103 & 0,542 & 5,424 & 0,000 \\
\hline
\end{tabular}

Sumber: Data Penelitian, 2019

Uji koefisien determinasi bertujuan untuk mengetahui bagaimana pengaruh variabel bebas menjelaskan variabel terikat dalam suatu penelitian. Hasil dari uji koefisien determinasi disajikan pada Tabel 12, sebagai berikut.

Tabel 12. Hasil Uji Koefisien Determinasi

\begin{tabular}{lllll}
\hline Model & & & & $\begin{array}{l}\text { Std. Error of the } \\
\text { Estimate }\end{array}$ \\
\hline 1 & $\mathrm{R}$ & $\mathrm{R}$ Square & Adjusted R Square & 1,74631 \\
\hline
\end{tabular}

Sumber: Data Penelitian, 2019

Berdasarkan Tabel 12, didapatkan hasil uji koefisien determinasi bahwa variasi kepatuhan pelaporan PKP di KPP Denpasar Timur dipengaruhi oleh variabel bebas yang digunakan sebesar 64,9 persen dan sisanya dipengaruhi oleh faktr lain yang tidak termasuk dalam penelitian sebesar 35,1 persen.

Hasil dari uji kelayakan model atau uji $\mathrm{F}$ terhadap variabel independen yang digunakan dalam penelitian disajikan pada Tabel 13.

Tabel 13. Hasil Uji Kelayakan Model (Uji F)

\begin{tabular}{lllllll}
\hline Model & & Sum of Squares & df & Mean Square & F & Sig. \\
\hline 1 & Regression & 412.583 & 2 & 206.291 & 67.645 & $.000^{\text {a }}$ \\
& Residual & 213.472 & 70 & 3.050 & & \\
& Total & 626.055 & 72 & & & \\
\hline
\end{tabular}

Sumber: Data Penelitian, 2019

Berdasarkan Tabel 13, hasil yang didapat dari uji $\mathrm{F}$ adalah reformasi administrasi pajak, dan implementasi E-Faktur berpengaruh signifikan terhadap kepatuhan pelaporan PKP di Kantor Pelayanan Pajak Pratama Denpasar Timur. Simpulan ini didapat dari hasil yang disajikan pada Tabe 13. dimana didapatkan

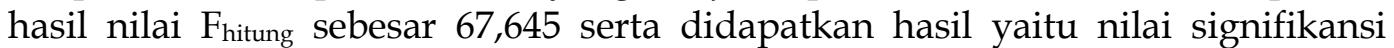
sebesar 0,000 dimana lebih kecil dari 0,05. Hasil dari pengujian $\mathrm{H}_{1}$ dan $\mathrm{H}_{2}$ disajikan pada Tabel 14, berikut.

Tabel 14. Hasil Uji Hipotesis (Uji t)

\begin{tabular}{lcccl}
\hline Model & $\begin{array}{c}\text { Koefisien Regresi } \\
(\mathrm{B})\end{array}$ & $\mathrm{t}$ & Sig. & Keterangan \\
\hline Reformasi Administrasi Pajak & 0,280 & 3,300 & 0,002 & Signifikan \\
Implementasi E-Faktur & 0,559 & 5,424 & 0,000 & Signifikan \\
\hline
\end{tabular}

Sumber: Data Penelitian, 2019

Berdasarkan hasil dari uji t $\mathrm{H}_{1}$ didapatkan hasil yaitu $\mathrm{H}_{1}$ diterima dan $\mathrm{H}_{0}$ ditolak maka pada penelitian ini terbukti adanya pengaruh positif antara reformasi administrasi pajak pada kepatuhan WP. Kesimpulan ini didapat dari diperolehnya nilai signifikansi yang lebih kecil dari 0,05 yaitu 0,002 serta koefisien regresi yang memiliki nilai positif 0,280 . 
Teori yang mendukung hasil dari penelitian ini adalah Theory of Planned Behavior. TBP memberikan penjelasan mengenai faktor yang mengakibatkan seseorang melakukan suatu tindakan dimana faktor tersebut adalah niat. Hubungan teori ini dengan penelitian yaitu tindakan dari PKP. Tindakan PKP yaitu kepatuhan PKP. Reformasi perpajakan yang terus dilakukan oleh DJP untuk menyempurnakan sistem perpajakan Indonesia yang kemudian sejalan dengan semakin mudahnya akses bagi PKP untuk melaksanakan kewajibannya sebagai WP dapat memotivasi PKP untuk taat pajak. Pelayanan yang diberikan semakin baik membuat PKP nyaman dalam melakukan pelaporan pajak dan pelaporan pajak dapat dilakukan secara efektif dan efisien. Fasmi \& Misra (2014) serta Antari \& Supadmi (2019) dalam penelitian yang dilakukannya mengenai modernisasi sistem administrasi perpajakan mendapatkan hasil bahwa modernisasi sistem administrasi perpajakan memiliki pengaruh signifikan pada tingkat kepatuhan pengusaha kena pajak. Apriliana (2013) serta Punarbhawa \& Aryani (2013) juga menemukan adanya pengaruh positif antara reformasi administrasi perpajakan dengan kepatuhan wajib pajak.

Berdasarkan hasil dari uji $\mathrm{t}_{2}$ didapatkan hasil yaitu $\mathrm{H}_{2}$ diterima dan $\mathrm{H}_{0}$ ditolak maka pada penelitian ini terbukti adanya pengaruh positif antara implementasi E-Faktur pada kepatuhan pelaporan PKP. Kesimpulan ini didapat dari diperolehnya nilai signifikansi yang lebih kecil dari 0,05 yaitu 0,002 serta koefisien regresi yang memiliki nilai positif 0,280. Rizqiah et al. (2014) dan Lingga (2015) dalam penelitiannya yang mengangkat topik serupa yaaitu mengenai implementasi E-Faktur pada kepatuhan pelaporan wajib pajak badan menemukan hasil yang sama yaitu kedua variabel tersebut berpengaruh positif. Penelitian Wijayanti \& Merkusiwati (2017) serta Novaria (2019) juga menyatakan hasil yang serupa bahwa adanya pengaruh positif antara E-system perpajakan pada kepatuhan wajib pajak. Untuk menjelaskan bagaimana PKP memanfaatkan E-faktur serta E-SPT dalam melakukan pelaporan didasari dari Technology Acceptance Model (TAM). TAM memberikan pemahaman mengenai pemanfaatan teknologi oleh pengguna. Pada penelitian ini didapatkan hasil dengan diimplementasikannya E-Faktur, PKP lebih patuh dalam melakukan pelaporan. Hal tersebut disebabkan dengan semakin mudahnya PKP dalam melakukan pelaporan dimana semua dapat dilakukan secara online.

\section{SIMPULAN}

Berdasarkan hasil analisis ditemukan hasil yaitu kedua hipotesis yang dibentuk diterima. Pada penelitian ini terbukti adanya pengaruh positif antara reformasi administrasi pajak pada kepatuhan WP dan adanya pengaruh positif antara implementasi E-Faktur berpengaruh positif dan signifikan terhadap kepatuhan pelaporan PKP. Semakin mudahnya akses bagi PKP untuk melaksanakan kewajibannya sebagai WP dapat memotivasi PKP untuk taat pajak. diimplementasikannya E-Faktur, PKP lebih patuh dalam melakukan pelaporan. KPP Denpasar Timur perlu meningkatkan pelayanan dan sosialisasi pelaporan dengan E-faktur. 


\section{REFERENSI}

Antari, N. L. P. Y., \& Supadmi, N. L. (2019). Pengaruh Penerapan Sistem Administrasi Perpajakan Modern, Kualitas Pelayanan dan Kesadaran Wajib Pajak Pada Kepatuhan WPOP. E-Jurnal Akuntansi Universitas Udayana, 26(1), 221-250.

Apriliana, R. (2013). Pengaruh Penerapan Sistem Modernisasi Administrasi Perpajakan terhadap Kepatuhan Wajib Pajak (Studi Empiris pada WPOP di Fakultas Ekonomi dan Bisnis Universitas Brawijaya Malang). Jurnal Ilmiah Mahasiswa FEB.

Arif, K. (2019). Apa Kabar Reformasi Perpajakan? Retrieved from https://ekonomi.bisnis.com/read/20190321/259/902717/opini-apakabar-reformasi-perpajakan.

Cronin, J. Joseph dan Steven A. Taylor. 1992. Measuring Service Quality. Journal Of Marketing, 56, pp.5-10.

Davis, F.D. 1989. Perceived Usefulness, Perceived Ease of Use, and Acceptance of Information System Technologhy. MIS Quarterly. 13 (3), h.319-339.

Devos, Ken. 2004. Penalties and Sanctions for Taxation Offences in Anglo Saxon Countries: Implications for Tax Payer Compliance and Tax Policy. Revenue Law Journal, Vol. 14.

Doran, Michael. 2009. Tax Penalties and Tax Compliance. Harvard Journal on Legislation, Vol.46. Georgetown University Law Center

Fadhilah, R. (2014). Pengaruh Good Corporate Governance Terhadap Tax Avoidance ( Studi Empiris Pada Perusahaan Manufaktur yang Terdaftar di BEI 2009-2011 ). Rogram Studi Akuntansi Universitas Negeri Padang.

Hartiyah, S., \& Suryanita. (2015). Analisis Faktor - Faktor Yang Mempengaruhi Tingkat Kepatuhan Pengusaha Kena Pajak Di Kantor Pelayanan Pajak (Kpp) Pratama Temanggung. Jurnal Ekonomi, Universitas Sains Al-Qur'an, Wonosobo., 10(2), 1-19.

James, Simon and Clinton Alley. 2004. Tax Compliance, Self-Assessment and Tax Administration. Journal of Finance and Management in Public Service, Volume 2 Number 2.

Max Everest-Philips. 2009. Tax Morale and State Building in Developing Countries. Journal of Development Policy Review, 28, pp.75-96.

Nopiana, P. R., \& Natalia, E. Y. (2018). Analisis sosialisasi pajak dan pemanfaatan teknologi informasi terhadap kepatuhan pelaporan spt wajib pajak di kepulauan riau. Jurnal Benefita, 3(2), 277-290.

Novaria, Y. (2019). Pengaruh E-System Dan Sanksi Perpajakan Pada Kepatuhan pelaporan PKP Badan Di Kpp Pratama Prabumulih. Jurnal Fakultas Ekonomi Universitas Sriwijaya., 1-26.

Obit, Siti Normala Sheikh. 2004. The Influence of Penalties on Taxpayers' Compliance: A Comparison of The Theoretical Models. IIUM Jurnal of Economics and Management 12, no.1. The International Islamic University Malaysia.

Omondi, Ochieng V; Nelson H. W. Wawire; Emmanuel O. Manyasa; and Gideon Kiguru Thuku. 2014. Effects of Tax Reform on Buoyancy and Elasticity of the Tax System in Kenya: 1963-2010. International Journal of Economic and Finance, Vol. 6, No. 10. Kenyatta University. 
Punarbhawa, I. G. A. B., \& Aryani, N. K. L. (2013). Pengaruh Reformasi Administrasi Perpajakan Dan Pengetahuan Perpajakan Terhadap Tingkat Kepatuhan Pengusaha Kena Pajak (PKP). E-Jurnal Akuntansi Universitas Udayana, 5(2), 381-397.

Rahayu, N. (2017). Pengaruh Pengetahuan Perpajakan, Ketegasan Sanksi Pajak, Dan TaxAmnesty Terhadap Kepatuhan Wajib Pajak. Jurnal Akuntansi Dewantara, 1(1), 18-21.

Rizqiah, F. A., Astuti, E. S., \& Yaningwati, F. (2014). Implementasi Elektronik Nomor Faktur (E-Nofa) Pajak Dalam Upaya Meningkatkan Pelaporan Wajib Pajak (Studi Pada Pegawai Pajak Di Kantor Pelayanan Pajak Pratama Surabaya Genteng). Ps Perpajakan, Jurusan Administrasi Bisnis, Fakultas Ilmu Administrasi Universitas Brawijaya, 1-9.

Sugiyono. (2017). Metodologi Penelitian Kuantitatif, Kualitatif, dan RED. Bandung: CV Alfabeta. 